\title{
Communication
}

[Comunicação]

\section{Effects of the food contaminant semicarbazide on testicular morphology of juvenile Wistar rats}

[Efeitos do contaminante alimentar semicarbazida na morfologia testicular de ratos Wistar jovens]

\author{
A. Ramos $^{1}$, A. Pereira ${ }^{2,3}$, A.S. Cabrita ${ }^{4}$, F. Capela e Silva ${ }^{3,5^{*}}$ \\ ${ }^{1}$ Departamento de Medicina Veterinária - Universidade de Évora e Universidade Lusófona de Humanidades e \\ Tecnologias, Portugal \\ ${ }^{2}$ Departamento de Zootecnia - Universidade de Évora, Portugal \\ ${ }^{3}$ Instituto de Ciências Agrárias e Ambientais Mediterrânicas-ICAAM - Universidade de Évora, Portugal \\ ${ }^{4}$ Instituto de Patologia Experimental - Faculdade de Medicina - Universidade de Coimbra, Portugal \\ ${ }^{5}$ Departamento de Biologia - Universidade de Évora, Portugal
}

Semicarbazide is a hydrazine derivative byproduct of azodicarbonamide, that can occur naturally, e.g. in algae, shrimps and eggs, and is formed from natural substances, e.g. arginine and creatine (Hoenicke et al., 2004). Formation of semicarbazide in processed food samples, such as carrageenan-containing food, treated with hypochlorite for disinfection and bleaching have been reported (Hoenicke et al., 2004). Semicarbazide is also present in glass jars and bottles closed with metal lids sealed with plastic gaskets that are foamed using the azodicarbonamide as blowing agent (Opinion..., 2005). Azodicarbonamide is not listed as a permitted food additive in Council Directive 95/2/EC [European Parliament and Council Directive No. 95/2/EC of 20 February 1995 on food additives other than colors and sweeteners]; however, it is used as a flour additive in some countries such as Canada, USA and Brazil owing to its dough-improving properties (de la Calle and Anklam, 2005). Recent studies proved that semicarbazide can also be formed in processed food such as coated poultry products and in bread prepared with azodicarbonamidecontaining flour (de la Calle and Anklam, 2005). The toxicity of semicarbazide is not well understood (Opinion..., 2005 and Nestmann et al., 2005), but experimental data showed semicarbazide acting as osteolathyrogen agent (Ramamurti and Taylor, 1959; Kundel, 1964;
Maranghi et al., 2009), and exerting pleiotropic effects on several organs/tissues (Maranghi et al., 2009) and marked alterations of spontaneous motor and exploratory behaviours (Maranghi et al., 2009). This study aimed to evaluate the effects of semicarbazide on testicular morphology of juvenile Wistar rats.

After ten days of acclimatizing, thirty weaning male Wistar rats, four-week-old, were individually weighed, identified, divided into three groups (ten animals/group) and kept in polypropylene cages with wood chip bedding under a $12 \mathrm{~h}$ light/dark cycle and room temperature of $22-24^{\circ} \mathrm{C}$, with water and food available ad libitum. The animals of control group $\left(\mathrm{G}_{0}\right)$ received the standard diet; the animals of the $G_{3}$ and $G_{6}$ groups received the semicarbazide hydrochloride (Sigma-Aldrich, Ref $\left.^{\mathrm{a}} \mathrm{S} 2201\right)$ in the diet at a concentration of $3 \mathrm{~g} / \mathrm{kg}$ and $6 \mathrm{~g} / \mathrm{kg}$, respectively. Body weight changes were recorded weekly on an electronic balance $(0.1 \mathrm{~g})$. At the end of the thirty days of experimental period, the animals were weighed and sacrificed by anesthesia overdose. After sacrifice, the testes were excised and fixed in $10 \%$ neutral phosphate-buffered (pH 7.4) formalin, dehydrated, embedded in paraffin, cut into $5 \mu \mathrm{m}$ sections and stained with hematoxylin and eosin, for the examination under light microscopy (Nikon Eclipse 600 microscope). All

Recebido em 4 de novembro de 2010

Aceito em 13 de setembro de 2011

* Autor para correspondência (corresponding author)

E-mail: fcs@uevora.pt 
the ten animals from each group were used and for each animal, 15 pictures from random seminiferous tubules were collected with a digital camera (Nikon DN100) at 200X magnification. For each picture, the area and the perimeter of the semineferous tubules, the area and the perimeter of the lumen of the semineferous tubules and the height of the germinative epithelium were measured using SigmaScan Pro5.0 software (SPSS, Chicago, IL, USA). For each seminiferous tubules, the height of the germinative epithelium was the mean of ten measures. From the results obtained, the average values for each animal and group were evaluated. All procedures involving the animals were approved by the scientific committee, supervised by a Federation of European Laboratory Animal Science Associations (FELASA) trained scientist and conforming to the regulations of the Portuguese law (Portaria 1005/92), following the European Union Laboratory Animal Experimentation Regulations. Statistical procedures were done as follows. The dependent variable "weight" was tested for the assessment of normality according to Kolmogorov Smirnoff test and homogeneity of variance according to Levene's test (Underwood, 1997). Following the findings of normality and homocedasticity, the variable weight was analyzed according to general linear model analysis of variance with two fixed factors: diet (three levels) and dates of weighing (with five levels). In the analysis of variance, it was considered as value significantly different, one whose probability of occurrence was greater than $95 \%(\mathrm{P}<0.05)$. When significant differences were found, means were compared by Tukey Kramer test (Underwood, 1997). All statistical analysis were performed by SPSS 16.0 software package.

The animals which were administered the semicarbazide showed significant reductions in body weight in a dose-dependent manner (Table 1).

Table 1. Body weight $(\mathrm{BW})$ of rats $(\mathrm{n}=10)$ during the experimental period ( $\mathrm{g}$; mean \pm standard deviation)

\begin{tabular}{cccccc}
\hline Groups & $\mathrm{BW}_{1}$ & $\mathrm{BW}_{2}$ & $\mathrm{BW}_{3}$ & $\mathrm{BW}_{4}$ & $\mathrm{BW}_{5}$ \\
\hline $\mathrm{G}_{0}$ & $80.70 \pm 10.1 \mathrm{aA}$ & $115.30 \pm 9.5 \mathrm{bA}$ & $154.40 \pm 13.3 \mathrm{cA}$ & $188.10 \pm 16.8 \mathrm{dA}$ & $214.70 \pm 24.5 \mathrm{eA}$ \\
$\mathrm{G}_{3}$ & $78.10 \pm 14.4 \mathrm{aA}$ & $84.2 \pm 14.7 \mathrm{aB}$ & $92.40 \pm 15.7 \mathrm{bB}$ & $96.10 \pm 17.0 \mathrm{bB}$ & $97.40 \pm 25.3 \mathrm{bB}$ \\
$\mathrm{G}_{6}$ & $74.90 \pm 14.8 \mathrm{aA}$ & $75.45 \pm 13.3 \mathrm{aB}$ & $79.18 \pm 16.0 \mathrm{aC}$ & $79.54 \pm 18.4 \mathrm{aC}$ & $76.18 \pm 20.6 \mathrm{aC}$ \\
\hline
\end{tabular}

Means followed by distinct lower letters in the same row and capital letters in the same column are different $(\mathrm{P}<0.05)$

The results showed that animals in $\mathrm{G}_{0}$ exhibited a behavior quite distinct from other groups $(\mathrm{P}<0.01)$. From the second weighing, there were higher weights $(P<0.01)$ in the animals of $G_{0}$ for the remaining. This trend continued and was accentuated with the progress of time, resulting in greater differences in weight achieved at the last weighing. For the $\mathrm{G}_{0}$, there were differences in the $G_{3}$ and $G_{6}$ greatly mitigated in increments of weight compared to initial weight. In $\mathrm{G}_{3}$, only after weighing three significant differences were observed in the results, at which point they began to show significant differences regarding the $\mathrm{G}_{6}$. Note that in $\mathrm{G}_{6}$, the highest dose of semicarbazide prevented significant increases in animal weight $(\mathrm{P}>0.05)$ over a number of weighings.

Untreated rats showed mostly normal testicular architecture with an orderly arrangement of germinal cells and Sertoli cells and normal successive stages of the spermatogenesis. Semicarbazide treatment induced testicular atrophy accompanied by the degeneration of germ cells within the seminiferous tubules, and the tubules were shrunken and greatly depleted of germ cells (Table 2 and Figure 1). 
Effects of the food...

Table 2. Histomorphometric changes in the seminiferous tubules of rats $(n=10)$ according to treatments (pixels; mean \pm standard deviation)

\begin{tabular}{ccccccc} 
Groups & $\begin{array}{c}\text { Epithelia } \\
\text { area }\end{array}$ & $\begin{array}{c}\text { Epithelia } \\
\text { height }\end{array}$ & $\begin{array}{c}\text { Tubular } \\
\text { area }\end{array}$ & $\begin{array}{c}\text { Tubular } \\
\text { diameter }\end{array}$ & $\begin{array}{c}\text { Lumen } \\
\text { area }\end{array}$ & $\begin{array}{c}\text { Lumen } \\
\text { diameter }\end{array}$ \\
\hline $\mathrm{G}_{0}$ & $60,947.01 \pm$ & $82.21 \pm$ & $77,083.09 \pm$ & $1,083.70 \pm$ & $16,136.08 \pm$ & $558.49 \pm$ \\
& $7,416.36 \mathrm{a}$ & $3.52 \mathrm{a}$ & $10,587,40 \mathrm{a}$ & $73.97 \mathrm{a}$ & $3,503.32 \mathrm{a}$ & $52.06 \mathrm{a}$ \\
$\mathrm{G}_{3}$ & $46,186.84 \pm$ & $61.53 \pm$ & $57,227.41 \pm$ & $971.48 \pm$ & $11,040,57 \pm$ & $464.70 \pm$ \\
& $9,524.99 \mathrm{~b}$ & $7.82 \mathrm{~b}$ & $12,280.02 \mathrm{~b}$ & $102.29 \mathrm{~b}$ & $3,121.04 \mathrm{~b}$ & $66.08 \mathrm{~b}$ \\
$\mathrm{G}_{6}$ & $39,384,20 \pm$ & $64.57 \pm$ & $47,494.95 \pm$ & $853.68 \pm$ & $8,110.75 \pm$ & $437.58 \pm$ \\
& $13,800.95 \mathrm{~b}$ & $16.05 \mathrm{~b}$ & $16,816.06 \mathrm{~b}$ & $158.03 \mathrm{c}$ & $3,775.71 \mathrm{~b}$ & $86.39 \mathrm{~b}$ \\
\hline
\end{tabular}

Means followed by distinct letters in the same column are different $(\mathrm{P}<0.05)$.
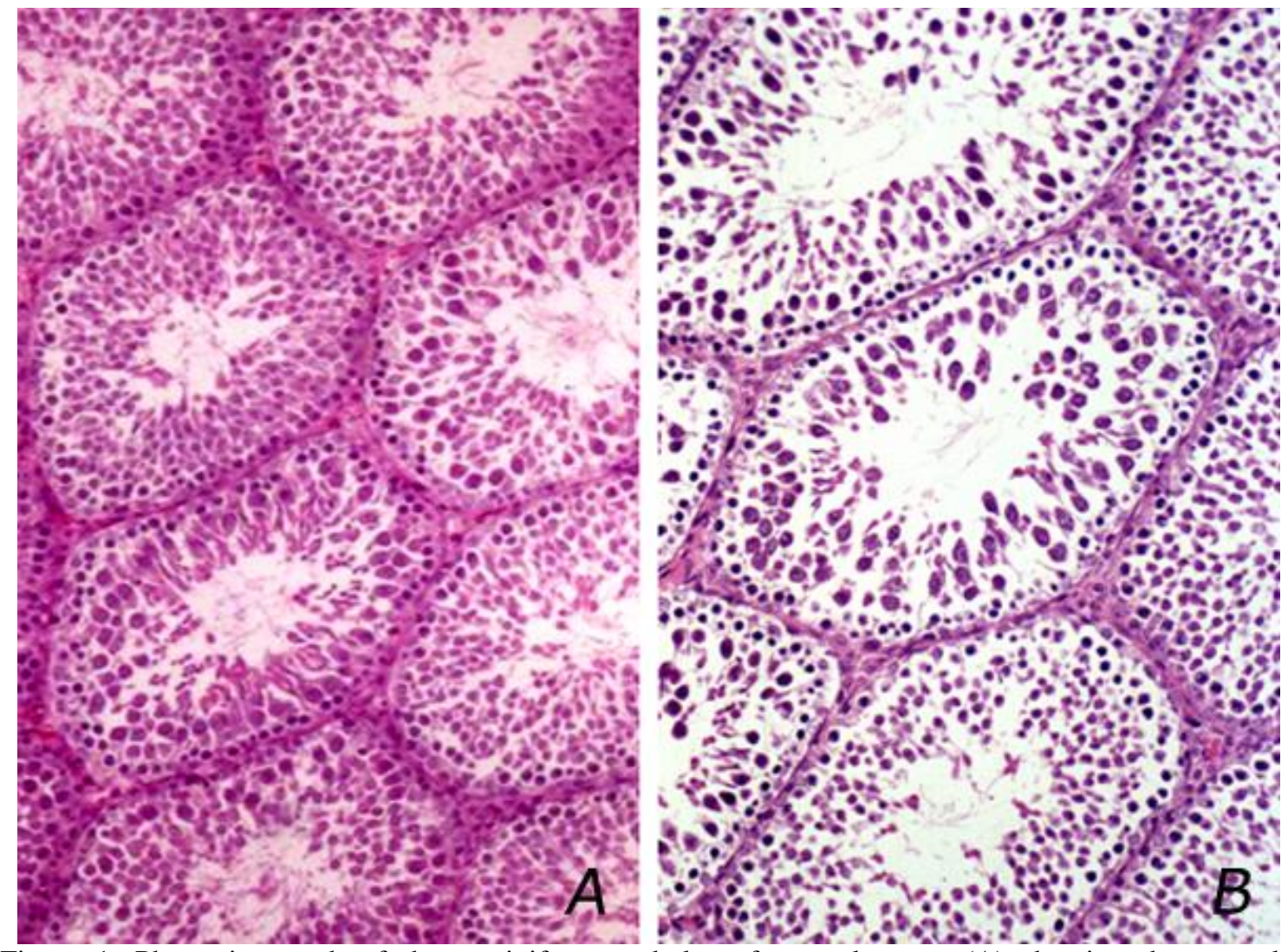

Figure 1. Photomicrograph of the seminiferous tubules of control group (A) showing the normal arrangement of germinal cells (H\&E, 100X). Testis of semicarbazide-treated rats (B) showing tubular atrophy with extensive degeneration of the germinal epithelium. The atrophic tubules contained degenerated Sertoli cells with few germ cells (H\&E, 100X).

The administration of semicarbazide to juvenile rats showed significantly decrease of body weight gain as reported by other authors (Maranghi et al., 2009) and exerted adverse effects by altering the normal testicular architecture and normal successive stages of the spermatogenesis. Similar effects were reported in rats treated with phthalates (Kondo et al., 2006) and dye blend (tomato red) (Sharma et al., 2008).
However, Maranghi et al. (2009) observed only subtle adverse effects of semicarbazide in testis of juvenile Sprague-Dawley rats by altering the percentage of testicular tissue programmed for spermatogenesis without affecting spermatogenesis itself. The mechanism of semicarbazide-induced toxic effects in the cardiovascular (i.e. aorta) and skeletal systems results from its binding to at least two 
enzymes, lysyl oxidase (Dawson et al., 2002) and semicarbazide-sensitive amine oxidase (Langford et al., 1999), both involved in the proper production and cross-linking of extracellular matrix (ECM) proteins, especially collagen and elastin. At high concentrations in vitro, semicarbazide may be weakly mutagenic as a result of the production of reactive oxygen species (ROS) (Hirakawa et al. 2003) which are involved in a variety of pathophysiological conditions of testes (Agarwal et al., 2006). Superoxide dismutase and glutathione peroxidase are major enzymes that scavenge harmful ROS in male reproductive organs (Fujii et al., 2003). Semicarbazide is a potent enzyme inhibitor, and the toxic effects in the reproductive system may result from inhibition of activities of those ROSscavenging enzymes. The present results showed that semicarbazide induce important changes during juvenile period in rat testicular morphology which probably may affect reproductive functions and further detailed studies are necessary to elucidate the mechanisms of action. This can be considered relevant for food safety in particular for children who represent a group of major exposure and susceptibility to semicarbazide

Keyword: semicarbazide, rat, Wistar, testes

\section{RESUMO}

O objectivo do presente trabalho foi avaliar os efeitos da semicarbazida na morfologia testicular de ratos Wistar jovens. Os animais foram tratados durante 30 dias com hidrocloreto de semicarbazida incorporado na dieta, nas concentrações de 0,3 e $6 \mathrm{~g} / \mathrm{kg}$. Os resultados obtidos revelaram uma diminuição estatisticamente significativa no diâmetro dos túbulos seminíferos, no diâmetro do lúmen dos túbulos seminíferos e na área ocupada pelo epitélio seminífero nos animais dos grupos experimentais em comparação com os animais do grupo controlo. Estes resultados evidenciam que a semicarbazida induz. alterações importantes no desenvolvimento testicular e sugerem um estudo mais aprofundado sobre os mecanismos de acção, dos efeitos a longo prazo, da reversibilidade das lesões e nas capacidades reprodutivas. Estes aspectos são relevantes numa perspectiva de segurança alimentar, em particular para as crianças, as quais representam um grupo de maior exposição e susceptibilidade à semicarbazida.

Palavras-chave: semicarbazida, rato, Wistar, testículos

\section{REFERENCES}

AGARWAL, A.; GUPTA, S.; SIKKA, S. The role of free radicals and antioxidants in reproduction. Rev. Curr. Opin. Obstet. Gynecol., v.18, p.325-332, 2006.

DAWSON, D.A.; RINALDI, A.C.; POCH, G. 2002. Biochemical and toxicological evaluation of agent-cofactor reactivity as a mechanism of action for osteolathyrism. Toxicology, v.177, p.267-284, 2002.

DE LA CALlE, M.B.; ANKLAM, E. Semicarbazide: occurrence in food products and state-of-the-art in analytical methods used for its determination. Anal. Bioanal. Chem., v.382, p.968-977, 2005.

FUJII, J.; IUCHI, Y.; MATSUKI, S. et al. Cooperative function of antioxidant and redox systems against oxidative stress in male reproductive tissues. Asian J. Androl., v.5, p.231$242,2003$.
HIRAKAWA, K.; MIDORIKAWA, K.; OIKAWA, S. et al. Carcinogenic semicarbazide induces sequence-specific DNA damage through the generation of reactive oxygen species and the derived organic radicals. Mutation Res., v.536, p.91-101, 2003.

HOENICKE, K.; GATERMANN, R.; HARTIG, L. et al. Formation of semicarbazide (SEM) in food by hypochlorite treatment: is SEM a specific marker for nitrofurazone abuse? Food Addit. Contam., v.21, p.526-537, 2004.

KONDO, T.; SHONO, T.; SUITA, S. Agespecific effect of phthalate ester on testicular development in rats. J. Pediatr. Surg., v.41, p.1290-1293, 2006.

KUNDEL, H.L. Osteolathyrism in the rat - An Xray diffraction study of collagen from normal and lathyritic rats. Radiology, v.82, p.67-76, 1964. 
LANGFORD, S.D.; TRENT, M.B.; BALAKUMARAN, A. et al. Developmental vasculotoxicity associated with inhibition of semicarbazide-sensitive amine oxidase. Toxicol. Appl. Pharmacol., v.155, p.237-244, 1999.

MARANGHI, F.; TASSINARI, R.; LAGATTA, $\mathrm{V}$. et al. Effects of the food contaminant semicarbazide following oral administration in juvenile Sprague-Dawley rats. Food Chem. Toxicol., v.47, p.472-479, 2009.

NESTMANN, E.R.; LYNCH, B.S.; MUSAVELOSO, K. et al. Safety assessment and riskbenefit analysis of the use of azodicarbonamide in baby food jar closure technology: Putting trace levels of semicarbazide exposure into perspective: a review. Food Addit. Contam., v.22, p.875-891, 2005.

Opinion of the scientific panel on food additives, flavourings, processing aids and materials in contact with food on a request from the commission related to semicarbazide in food. EFSA J., v.219, p.1-36, 2005.
PORTARIA No 1005/92. Normas técnicas de protecção dos animais utilizados para fins experimentais e outros fins científicos. Ministérios da Agricultura, da Educação, da Saúde e do Comércio e Turismo, Portugal. Portaria n. ${ }^{\circ}$ 1005/92, de 23 de Outubro, Diário da República I Série B, p.4930-4942, 1992.

RAMAMURTI, P.; TAYLOR, H.E. Skeletal lesions produced by semicarbazide and experimental analysis of the action of lathyrogenic compounds. J. Bone Joint Surg. Br., v.41-B, p.590-599, 1959.

SHARMA, S.; GOYAL, R.P.; CHAKRAVARTYA, G. et al. Toxicity of tomato red, a popular food dye blend on male albino mice. Exp. Toxicol. Pathol., v.60, p.51-57, 2008.

UNDERWOOD, A.J. Experiments in ecology: their logical design and interpretation using analysis of variance. Cambridge: Cambridge University Press, 1997. 522p. 